\title{
CULTURAL INSTITUTIONS AS A COMBAT SPORT. REFLECTIONS ON THE EUROPEAN ROMA INSTITUTE
}

\author{
TINA MAGAZZINI ${ }^{1}$
}

\begin{abstract}
This article aims at problematizing the relation between identity recognition, economic redistribution, and political representation in the debate around Roma inclusion in contemporary Europe. Given that culture has increasingly become politicized, by analyzing the emergence of the European Roma Institute for Arts and Culture I reflect on the political and economic potential and drawbacks that cultural identity holds in a European society in which capitalism has turned into a cultural trait.
\end{abstract}

Keywords: European Roma Institute, cultural diversity, recognition, minority inclusion

Summary: I. InTROdUCtion; II. A EUROPEAN ROMA INSTITUTE (FOR ARTS AND CULTURE); III. DISCRIMINATION OF A "TRUE EUROPEAN MINORITY" AND THE ETHNICIZATION OF MARGINALITY; IV. Roma Politics, ERI'S Positioning and a Note on Methodology; V. Main Criticisms. The CUltural, THE ECONOMIC AND THE POLITICAL; V.1 Cultural Concerns (or Concerns about Culture) and Counter Arguments; V.2 Socioeconomic Concerns and Counter Arguments; V.3 Political Concerns and Counter Arguments; VI. ConClusions. On EliTISM, CULTURE AND ‘THE IMPORTANT THINGS IN LIFE'

British democracy recognizes that you need a system to protect the important things of life, and keep them out of the hands of the barbarians. Things like the opera, Radio Three, the countryside, the law, the universities...both of them!

(Sir Humphrey, Yes Prime Minister)

\footnotetext{
${ }^{1}$ Human Rights Institute. University of Deusto, Bilbao (tina.magazzini@deusto.es).

An earlier version of this article was presented at the IPSA congress in Poznan, Poland, 23-28 July 2016. I would like to thank Julija Sardelic and Diana Popescu for organizing the panel 'From Misrecognition to Redistribution: Ethnic Discrimination and the Politics of Difference' and providing insightful comments, as well as the anonymous reviewers for their helpful feedback.
} 


\section{INTRODUCTION}

Within the debate on cultural diversity management and antidiscrimination in European societies, the Roma ${ }^{2}$ have come to constitute-particularly in the last decade - a minority towards which a full set of ad hoc integration legislation, measures and policies have been adopted.

In parallel there has been a rapidly growing literature in the fields of political science and sociology addressing Roma representations in politics and policies. The increase in research on Roma-targeted policies from scholars such as Aidan McGarry, Mihai Surdu, Peter Vermeersch, Huub van Baar, Katrin Simhandl, Martin Kovats, Joanna Kostka, Nicolae Gheorghe, Will Guy, Nidhi Trehan (among others) have explicitly addressed socio-economic mobility of Roma migrants in the context of contemporary European policies on migration and ethnic minority protection.

This literature necessarily builds upon anthropological reflections on the nature of ethnic identity and identification, and call into cause debates such as Spivak's strategic essentialism, how to operationalize group 'ethnicity' and 'culture' into rights (and negation of rights) linked to these identity markers, and discussions around the legacy of Gyspsy Studies in modern Romani scholarship. While a comprehensive review of the existing literature on minority rights in general, and Roma identity politics in particular, is out of the scope of this article ${ }^{3}$, it is loosely within this strand of research that the following reflections can be situated.

This article aims at locating the recent European recognition and categorization of the Roma as an ethno-cultural minority by analyzing the emergence of a new institutional body intended at promoting Roma culture-the European Roma Institute for Arts and Culture. The contribution of this article to the wider discussion on identity and cultural integration that this special issue tackles is to analyze and problematize the existing tensions revolving around the issues of cultural legitimacy and knowledge production of minority cultures. Because narratives about identity are defined by structures of power (how they are told; by whom; in what context, etc.) I believe that a better understanding of the creation of the European Roma Institute, and the resistance it encountered, has implications that go beyond the potential for success or for harm that this specific institute holds. Such reflections aim at raising some of the dissonances, overlaps and contradictions in how identity politics can be framed in a European society in which capitalism has turned into a cultural trait.

\footnotetext{
${ }^{2}$ The term "Roma" is used in political documents of the European Commission, European Parliament and the European Council as an umbrella expression "which includes groups of people who have more or less similar cultural characteristics and a history of persistent marginalisation in European societies, such as Sinti, Travellers, Kalé, etc.” (European Commission, 2010). This definition, its usage in policy documents and its implications will be problematized later in the article (see section III).

${ }^{3}$ For a thorough analysis of expert practices of Roma classification see the recently published book Those Who Count (Surdu, 2016).
} 
Since the narratives of poverty migration and hostility towards the 'ethnic other' are often conflated, the initiatives to tackle such issues can also find themselves entangled into more than one aspect at once.

In other words, in an enlarged European Union in which Roma from CEE countries have been the great losers of the nineties' transition to a market economy (Kovats, 2012; Sigona, 2011; Vermeersch, 2012) how can the risk of displacement (in which identity politics tend to displace struggles for redistribution), reification (the essentialization of a culture or a minority) and misframing (the political dimension of misrepresentation) be dealt with and overcome? (Fraser, 2000, p. 108, 2005, p. 9) How does a European Roma Institute for Arts and Culture affect other policies addressed to the same minority, and what are the strengths and liabilities of this project?

In order to explore this conundrum, this article will a) outline what the object of the study is -ERI-, and why it is relevant b) provide an overview of the context, in the form of a brief history of how we got to the present debate, and of who the main stakeholders are c) give an account on how the information was collected and situate the specificities of the ERI debate d) draft a resumed yet systematized assessment of what the main criticisms that have been brought so far to the ERI project are, how they have been addressed by the supporters of the Alliance for ERI, and organize them according to the three broad themes that emerge as the most relevant ones for this debate (the cultural, the economic and the political) ${ }^{4}$. The vocabulary used (recognition, redistribution, misframing) is borrowed from Nancy Fraser's theory of justice, but the approach taken in this article incorporates the critiques moved to Fraser (and much of the recognition theory) which, rather than seeing the problems of displacement and reification as pertaining primarily to social movements and their potentially contradictory claims for recognition, acknowledge the central role of institutions and of the political arena.

\section{A EUROPEAN ROMA INSTITUTE (FOR ARTS AND CULTURE)}

In March 2015 a joint article by George Soros, founder and chair of the Open Society Foundations, and Thorbjørn Jagland, currently serving his second term as the Secretary General of the Council of Europe, announced on the European Voice that a European Roma Institute (from now on ERI) was being set up (Soros \& Thorbjørn, 2015).

While acknowledging that some of the most salient issues with regard to Europe's Roma population are racism and inequality of opportunity, the raison d'être of ERI as an Institute "of Arts and Culture" was presented as fundamentally a matter of

\footnotetext{
${ }^{4}$ This analysis is rooted in the conviction that some of the most salient issues in contemporary's Europe culturally complex societies are class, exclusion and racism. For the purpose of this article I will concentrate on the discussion around Roma culture/ recognition, with the European Roma Institute debate as a backdrop, but questions relating to power dynamics and structural (particularly socio-economic) inequalities are impossible to overlook completely.
} 
recognition and of implementing art. 27 of the ICCPR to the right for Roma to "enjoy their own culture"; in short, it has to do with those traits which the first article of this special issue has identified as defining cultural elements of minority groups.

More specifically, the opening statement of the article explaining the creation of ERI read:

"For more than four decades Europe’s Roma community have wanted to establish an institution that would give their music, art and unique traditions their own stage. Across the continent, such bodies exist to celebrate an array of cultures, nationalities and identities. Yet, there is nothing of this kind for Roma. Many feel this absence, particularly among Romani campaigners, educators and intellectuals. It compounds a sense of exclusion and denies all of us the opportunity to celebrate the Roma influence on our shared cultural life. We are joining forces to help put this right”(Soros \& Thorbjørn, 2015).

The article then went on to speak about exclusion, marginalization and segregation, a vocabulary which Romani studies scholars, policy analysts and the general public alike have grown accustomed to find systematically linked to the descriptions of Europe's Roma. The answers to the question that gave the title to the story ("Why we are setting up a European Roma Institute") offered by Soros and the CoE's Secretary General are however fundamentally rooted in matters of cultural identity, rather than socio-economic ones. The main justifications provided for the need of the ERI are: 1) Combating the negative stereotypes about Roma 2) The belief that ERI will become a powerful source of self-esteem: "It would act as an important symbol-and symbols are important, as is the ability to tell one's story in one's own voice. [...] Perhaps most important, it would provide a landmark for Roma children to look upon and feel a sense of belonging and pride.” (Soros \& Thorbjørn, 2015) 3) Explore the ways in which Roma life has shaped, and been shaped, by other cultures and forces, underlining similarities as well as differences (this point is however expressed more as a tentative possibility, the main issue remaining that of stereotypes and self-esteem).

This core message was reiterated a few months afterwards, when in September 2015 Jagland issued the statement: "the Council of Europe wants to help celebrate the contribution of Roma art, history, and tradition to our shared cultural heritage. [...] The European Roma Institute for Arts and Culture will spread greater understanding of Roma culture and challenge unhelpful stereotypes. I hope that over time it will become a source of pride and self-esteem for our European Roma citizens" (Council of Europe, 2015). These affirmations were accompanied by the specification that the project will be Roma-led -which it is: the bios of the 16 members of the Alliance for ERI are available online, as are the details of the four NGO members ${ }^{5}$ - and that funding, resources and political support would be provided by the Council of Europe and the Open Society

${ }^{5}$ See the webpage of the Alliance for the European Roma Institute. 
Institute (which according to the consultation document prepared by the Council of Europe Secretariat Towards a Creation of a "European Roma Institute" in 2014, will be contributing 200,000 euros each per year) ${ }^{6}$.

For anyone who has been following the politics of Roma identity over the past years, it shouldn't come as a surprise that the creation of the ERI (or rather, the declaration of intention of the creation of the ERI) was accompanied by perplexities and criticism "from the inside": on whether this is an endeavor that should be taken up by a public body such as the Council of Europe; on whether this is an effective avenue to pursue the stated aims; and on whether Roma should be framed as a cultural minority to begin with. The relatively small but vastly diverse universe of academics, policy makers, activists, non-governmental and international organizations who can loosely be defined as being invested in the cause of advancing rights for Europe's Roma have had as divergent opinions on ERI as their background and scopes are.

Arguably, the heated and often personal and confrontational debates that this debate triggered go beyond the set-up of the ERI itself. Revolving around the concepts of Roma authenticity, legitimacy, ethnic representation and cultural hegemony such exchanges have tapped into a complex set of underlying assumptions that often go unproblematized, and whose analysis can help bring some clarity to understanding wider struggles around Roma identity politics.

So far no criticism towards ERI has come from right wing parties nor from mainstream media (possibly, because it is still in the making), but the accusations between Roma and pro-Roma associations, activists and academics has been particularly polarizing.

On the one hand, ERI has been welcomed by a number of individuals and organizations as a beacon of hope for addressing stereotypes and countering a negative image of Roma identity that is rife in mainstream media and politics; on the other hand it has been accused of doing more harm than good to the advancement of the Roma cause by others. The wider question that I believe this controversy raises is: how does the cultural and identitarian debate (the recognition and valorization of Roma culture via an institute backed by the Council of Europe) reflect and/ or shape the political process of representation and of economic redistribution at the EU policy-making level?

\section{DisCRIMINATION OF A “True EUROPEAN MiNORITY” AND THE ETHNICIZATION OF MARGINALITY}

As illustrated in the first article of this issue, Europe's approach to the democratic management of cultural diversity has been -and is- a complex and everchanging compromise between political ideals (the defense of cultural diversity as an ethical imperative), practical needs or potential conflicts that require regulation, and the

\footnotetext{
${ }^{6}$ In the CoE Secretariat consultation document the estimates given speak about the CoE contributing to one third of the budget with $200 \mathrm{~K}$ euro per year, OSF also contributing to one third of the budget with 200K euro per year, and the rest coming from other funders (Council of Europe, 2014, p. 4).
} 
existing gaps and inconsistencies in interpretations of what the "cultural third sphere" to be defended and promoted amounts to (see Ruiz Vieytez in this issue). While only recently acknowledged by EU policies, ethnic origin and religion are increasingly important markers recognized as basis for discrimination.

The latest European legislation seems to take stock of these developments and of the changing attitudes towards cultural diversity, as demonstrated by the 'Tackling discrimination' section of the European Commission DG Justice Legislation's repository opening statement. Such inception reads "For many years the focus of EU action in the field of non-discrimination was on preventing discrimination on the grounds of nationality and gender. A few years ago, however, the EU countries approved unanimously new powers to combat discrimination on the grounds of racial or ethnic origin, religion or belief, disability, age or sexual orientation" (European Commission DG JUST, 2016).

The attention towards relatively new categories of discrimination (where the "newness" refers to the categories and not to the discriminations, obviously) with regard to ethnic origin, sexual orientation, age, religion/ beliefs and disability are important steps forward in anti-discrimination laws and policies. If compared to the Eurobarometer Reports of the seventies, eighties and nineties, the difference in vocabulary, content and concerns are strikingly telling ${ }^{7}$. Additionally, beyond the abovementioned categories (and the possibility of multiple and intersectional discrimination between them), in the last two decades-with a steep curve in policy measures over the past few years - the Roma have come to be recognized, or constructed, as a "category" of its own in European directives, recommendations, and reports (Surdu \& Kovats, 2015). Generally not subsided under neither of the said groups, yet they are invariably included amongst those minorities considered to be most at risk of discrimination (a quick look to any survey on attitudes towards minorities in Europe shows that this concern is well-founded) ${ }^{8}$, and are often featured in surveys and policies as a stand-alone category.

This trajectory is the product of both political and historical circumstances: the Balkan wars of the nineties and the breakup of Yugoslavia, the swift move of that

\footnotetext{
${ }^{7}$ In a 1970 report detailing the results of a survey study on the "Europeans and European Unification” (in the six countries of the European Community at the time), a large section was dedicated to analyzing what is filed under "Cultural resistance of the ethnocentric type". This was described as inability to identify with a larger community, with the attachment to one's cultural identity (expressed as the fear to lose this identity) and translated into "a deeply felt, basic kind of resistance [towards a European integration]" (Commission of the European Communities, 1970, p. 19). It therefore seems that we have come a long way towards building a Europe that is more open to cultural diversity, despite the recent rise of populist anti-immigrant parties.

${ }^{8}$ Every second Roma interviewed for the EU Minorities and Discrimination Survey (EU-MIDIS) in 2011 reported that he or she had been discriminated against in the previous 12 months (European Union Agency for Fundamental Rights, 2011), and the EU-MIDIS II from 2015 shows similar data (European Union Agency for Fundamental Rights, 2016). According to the Pew Research Center, in 2015, 86\% of Italians, $60 \%$ of French, and more than a third of Spanish, German and British populations hold negative sentiments about Roma (Stokes, 2015).
} 
region towards a market economy, the breakup of the USSR and the EU's increased attention towards minority protection and rights with the Copenhagen criteria for accession, in ways however that inherently encouraged "form over practice" (Vermeersch, 2012, p. 6). As a result, Central European countries adopted the Framework Convention for the Protection of National Minorities and most of them currently recognize the Roma as a national minority, but discrimination has all but decreased over the past two decades. In most of Western European, despite the fact that Roma communities have been residing for centuries in countries such as Italy, France or Germany, they have not been granted the status of national minority ${ }^{9}$, and the EU enlargements of 2004 and 2007 have been narrated by mainstream media as carrying the danger of a ‘Roma invasion’ from the East (Solimene, 2011).

With Recommendation 1203 "Gypsies in Europe” (1993), based on a report by Josephine Verspaget (who later became Chair of the Council of Europe's Special Group on Roma/Gypsies) the Parliamentary Assembly of the Council of Europe identified the Roma (even though the terminology 'Roma' in policy emerged later, and the EU documents from the early nineties invariably refer to 'Gypsies') as a "true European minority", and more specifically a cultural one, stating that "[a] special place among the minorities is reserved for Gypsies. Living scattered all over Europe, not having a country to call their own, they are a true European minority, but one that does not fit into the definitions of national or linguistic minorities. [...] Gypsies greatly contribute to the cultural diversity of Europe $[. .$.$] be it by language and music or by their trades$ and crafts" (Council of Europe, 1993, p. 1). ${ }^{10}$

The Europeanization of the Roma issue was further institutionalized by the European Parliament resolution of January 2008 which called for a EU Strategy on Roma, based on a motion by Hungarian MEP Lívia Járóka (Jároká, 2008) ${ }^{11}$, and eventually found a middle ground between European political will (and funding) and national responsibility in the approval of the National Roma Integration Strategies (European Commission, 2012) ${ }^{12}$.

\footnotetext{
${ }^{9}$ The Roma are officially recognized as a national minority in Austria, Croatia, the Czech Republic, Hungary, Montenegro, FYR Macedonia, Norway, Poland, Romania, Serbia, Slovakia, Sweden, Ukraine; as a 'traditional national minority' in Finland, and as a 'racial group protected under the Race Relation Act of 1976' by the United Kingdom. They have no special legal status in most other European countries (Bunescu, 2014, pp. 66-67).

${ }^{10}$ Italics added. For a critical analysis of how, over the 1990s, the Roma issue has been increasingly defined in cultural terms, see the article "Problems of Intellectual and Political Accountability in Respect of Emerging European Roma Policy” (Kovats, 2001). Kovats' main argument is that framing the presence of the Roma people in Europe as a matter of discrimination and of cultural identity, rather than identifying the causes of socio-economic problems faced by many Roma people such as poverty, unemployment, poor housing, health etc. serves the interests of mainstream institutions, but is detrimental to the Roma communities themselves.

${ }^{11}$ The Parliament's resolution was supported by the European Roma Policy Coalition (ERPC) as well as by governments of member countries of the Decade of Roma Inclusion, an international initiative launched in 2005 by the World Bank and the Open Society Institute to support the adoption and implementation of Roma-targeted action plans in eleven former communist countries plus Spain.

${ }^{12}$ The decision of the European Commission to adopt a common strategic framework was largely based on the inability demonstrated by European governments to guarantee access to fundamental rights to its
} 
The growing commitment of European institutions towards the so-called 'Roma issue' has given heed to questions related to the need to adopt social and cultural policies explicitly directed at an ethnic minority (which however shy away from being affirmative action policies) and to whom the beneficiary population of such policies is composed of ${ }^{13}$. Therefore to identify or be identified as 'Roma' has come to constitute, particularly in the last decade, an ad hoc category in surveys on discrimination, inclusion/exclusion and marginalization. For instance, the standard classification of discriminated groups according to the latest Eurobarometer Report "Discrimination in the EU in 2015" can be appreciated in the following sample question: "Do you have friends or acquaintances who are...? 1) People whose ethnic origin is different from yours 2) Roma 3) Gay, lesbian or bisexual 4) Disabled 5) Of a different religion or have different beliefs than you 6) Transgender or transsexual” (European Commission DG JUST, 2015, p. 10).

According to the formulation of the survey we can draw the conclusion that Roma should not be treated as an ethnic minority within other "people whose ethnic origin is different from yours", nor as a group which has "different beliefs" from the mainstream, but rather as a category of their own. The previous Eurobarometer of 2012 went further, and included a specific chapter titled "The case of the Roma" which presented Roma as "Europe's biggest ethnic minority” (European Commission DG JUST, 2012, pp. 107-117) yet at the same time it clearly set them apart from the section on "Ethnic origin as grounds for discrimination" (European Commission DG JUST, 2012, pp. 28-34). Similarly, the 2014 Report by the Secretary General of the Council of Europe "State of Democracy, Human Rights and the Rule of Law in Europe" featured a stand-alone category of Roma ${ }^{14}$ which was set apart from the section on "Ethnic and national minorities” (Jagland, 2014, pp. 46-48).

In practice, it seems to be a banal platitude to state that Roma are an ethnic minority ${ }^{15}$ (as a matter of fact, they are generally presented as Europe's largest and most discriminated against ethnic minority), even though one that comprises of many highly diverse and dispersed groups (European Commission DG EMPL, 2004, p. 6; Tremlett, 2014) ${ }^{16}$, but their ethnicity is framed as somehow of a 'different kind' from that of most

Roma minorities through the already existing policies and legislation, such as the Equal Treatment directive (European Commission, 2000).

13 Since European institutions have no binding power over how each state chooses to identify and recognize its minorities, every country has built its own Roma strategy identifying its beneficiaries based on the national perception of what the 'problem' is and who counts as 'Roma' (Surdu, 2016).

${ }^{14}$ In this report, the definition used is the following: "the term "Roma" used at the Council of Europe refers to Roma, Sinti, Kale and related groups in Europe, including Travellers and the Eastern groups (Dom and Lom), and covers the wide diversity of the groups concerned, including persons who identify themselves as Gypsies.”

15 The issue of whether they are one ethnic minority or many is debatable. Roma elites have however always claimed, to the best of my knowledge, that despite great diversity they constituted one people, and that claims to the contrary were attempts to divide and disempower the Roma movement. In 2000, the International Romani Union (IRU) publically announced that the Roma people constituted a nation.

${ }^{16}$ The situation of the Roma in an enlarged European Union released by the EC DG Employment and Social Affairs (2004) specified: "At a number of points in this study, the term "Roma" or "Romani” is used as shorthand for the broad umbrella of groups and individuals. In no way should this choice of 
other ethnicities -even though there is no legal definition of ethnicity, as discussed in the first article of this special issue and elsewhere (see Ruiz Vieytez, 2014, p.14). Thus, if ethnic origin alone (in the sense of constituting a visible minority with a shared Indian ethnic origin) is considered insufficient to understand the representation of Roma identity in the public sphere, the issue of cultural specificity must be addressed (how does it differ from mainstream European national cultures, or how has it been constructed as being different from the mainstream?).

The Council of Europe, as mentioned earlier, has played an important role in establishing a narrative that puts the concept of a shared Roma cultural identity at the center of the discourse. Almost one decade after the earlier cited Recommendation 1203 (1993) the Parliamentary Assembly of the Council of Europe passed another Recommendation 1557 (2002) on the "Legal situation of the Roma in Europe", picking up and developing the "Gypsies in Europe" document, but also introducing a radically new element, the concept of Roma as a 'socially disadvantaged group'. Point 4 of the recommendation reads: "Roma form a special minority group, in so far as they have a double minority status. They are an ethnic community and most of them belong to the socially disadvantaged groups of society" (Parliamentary Assembly of the Council of Europe, 2002).

While it is well documented that the Roma are amongst the groups most at risk of discrimination, and that there are wide gaps in the access to education, housing, health and employment between Roma and non Roma (European Union Agency for Fundamental Rights - UNDP, 2012) by framing this as a sort of intrinsic characteristic of the Roma themselves (and not of the structural and institutional racism of Europe's majoritarian societies, surmountable by changing the dynamics and power relations at play within these societies) within a wider framework that, up to that moment, had emphasized Roma's minority culture status, it risks conflating the two issues. While well intentioned, and founded upon a legitimate concern for a real situation of disadvantage, this kind of language can potentially entrench, rather than help overcome, stereotypes on Roma, naturalizing the criteria used to evaluate Roma's human capital as one of poverty, exclusion and marginalization. Examples of this approach of thinking of the Roma as intrinsically problematic abound, and further articulation of this can be seen in point 9 of the same recommendation, which states "[t]he majority population must accept Roma into society without assimilating them, and support Roma as a disadvantaged social group. Roma have to accept the rules governing society as a whole, and they can be called upon to be more active in handling their own problems, but this must be associated with appropriate conditions, encouragement and incentives provided by the state.” Above and beyond the paternalistic tone, such statement seems to identify the Roma as both the victims and responsible of exclusion, forgetting that the drivers of marginalization are wider structures of economic and political power ${ }^{17}$, and

terminology be taken as an endorsement of approaches aimed at homogenizing Roma and other groups perceived as 'Gypsies' in Europe or at eliminating the rich diversity among Roma, Gypsies, Travellers and other groups perceived as 'Gypsies'.”

${ }^{17}$ Point 5 of the same recommendation states: "Most Roma are currently faced with a rather severe economic situation in most of the member countries of the Council of Europe. Despite efforts in the social 
making the implicit assumption that Roma culture is somehow at odds with 'the rules governing society as a whole'.

This definition is not inconsequential, as it has informed much of the recent European policy-making on Roma inclusion. It is interesting to observe how, in different settings, the definition of 'who the Roma are' has been declined to fit different agendas over the past years (Surdu, 2016), and particularly the definition of the Roma that ended up being adopted in the European Commission Communication 173 "An EU Framework for National Roma Integration Strategies up to 2020” is (European Commission, 2011). This reads:

“The term 'Roma' is used-similarly to other political documents of the European Parliament and the European Council-as an umbrella expression which includes groups of people who have more or less similar cultural characteristics, such as Sinti, Travellers, Kalé, Gens du voyage, etc. whether sedentary or not; around $80 \%$ of Roma are estimated to be sedentary” (European Commission, 2011, p. 2).

This definition follows and references another similar one, the Commission Staff Working Document (European Commission, 2010) which is cited at note 2 of this article, and with which the only significant difference is that the definition from 2010 does not explicitly cite the Gens du voyage ${ }^{18}$, it includes the sentence "they share a history of persistent marginalization in European societies", and (importantly) there is no mention of the issue of nomadism/ sedentary lifestyle. It thus seems reasonable to interpret this gradual shift in definitions as an attempt, on behalf of the European Commission, to emphasize the socio-economic dimension of disadvantage of the Roma while moving away from the cultural stigma element-particularly in the form of atavic and romanticized nomadism that the Council of Europe had been promoting. The shift towards a focus on the socio-economic dimension is substantiated by the contents of the Communication on the Framework for the National Strategies of 2011, which opens with a section titled "Improving the situation of Roma: a social and economic imperative for the Union and its Member States", and the fact that in the whole document the word socio-economic appears 29 times, while the word culture not even once.

field, the market economy, especially the neo-liberal version of it, has marginalized disadvantaged social groups including Roma even in the most developed European countries. In central and eastern Europe the economic and political transition has aggravated their socially disadvantaged situation” (Parliamentary Assembly of the Council of Europe, 2002).

${ }^{18}$ The suggestion that the addition might not be coincidental is purely speculative. However, given the statement of Viviane Reding, DG Justice Commissioner at the time, who likened Sarkozy's government deportation of over a thousand Romanians and Bulgarians of Roma ethnicity to Vichy France's treatment of Jews during the second world war-a policy that was developed after an incident in Loir-et-Cher involving French Gens du voyage- it is not so far-fetched (Doytcheva, 2015). 


\section{Roma Politics, ERI’s Positioning ANd a Note ON Methodology}

Above and beyond the Council of Europe, the European Commission, and the European Parliament, some of the most relevant actors, stakeholders and policies in shaping the discourse on Roma identity in the past decades have been ${ }^{19}$ :

- The IRU (International Roma Union), which promoted the First Romani Congress in 1971 and obtained consultative status at the UN, and can be seen as the birth of Romani nationalism;

- The Germany-based Roma National Congress (RNC), which advocated for the rights of Roma immigrants in the 80s and 90s;

- The European Roma and Travellers Forum (ERTF), created in 2004 with the support of the Finnish government, functions as an umbrella body of different Romani grassroots organizations. It managed to maintain privileged relations with the Council of Europe, where it held consultative status until 2015. It developed the largest and possibly most representative network of Roma civil society, but lost much of its leadership and status in the past few years. On 30 March 2015, the ERTF issued a (explicitly negative) position paper on ERI;

- Academia, and particularly the Gypsy Lore Society -founded in 1888 in Great Britain with the stated goals of promoting "the study of Gypsy, Traveler, and analogous peripatetic cultures worldwide; [the] dissemination of accurate information aimed at increasing understanding of these cultures in their diverse forms” (The Gypsy Lore Society, 2016)- and the European Academic Network on Romani Studies (EARNS), a joint programme of the European Commission and the Council of Europe created in 2011 as an interface between academic researchers and political decision makers, with the objective of allowing "for the implementation of better conceived policy initiatives based on reliable evidence" but whose funding was not renewed in 2015 (Matras, 2015). Opinions within these networks have been mixed, but Yaron Matras, a linguist and member of EANRS' Scientific Committee, has been one of the most vocal critics of ERI;

- The Project on Ethnic Relations (PER, 1991-2012) was founded in anticipation of interethnic conflicts that were to erupt following the collapse of Communism with the support of the US Department of State. It had a prominent role in setting the agenda for the joint Council of European and OSCE Human Dimension Seminar, and included leading activists Nicolae Gheorghe and Andrzej Mirga (one of the founders of the Alliance for ERI), as well as Romani scholar and linguist Ian Hancock, and resulted in the creation of a 'Contact point for Roma and Sinti';

- The Open Society Foundations and George Soros, the key supporter of ERI, has been involved with pro-Roma projects for over two decades, promoting initiatives such as the European Roma Rights Centre (ERRC), the Roma

\footnotetext{
${ }^{19}$ A full analysis of the Romani civil society movements and NGOs is out of the scope of the analysis, nor could a few paragraphs do it justice. The purpose of this section is simply to situate ERI within the constellation of Roma and pro-Roma institutions, associations and activist groups that have emerged in the past few decades. For a more in-depth analysis, see, among others (Bíró, Gheorghe, \& Kovats, 2013; Bunescu, 2014; Friedman et al., 2015; Matras, 2013).
} 
Participation Programme, the European Roma Coalition Programme (ERCP), the European Roma Grassroots Organization (ERIO) and the Roma Education Fund (REF);

- Other initiatives include the European Language Curriculum and the Central Council of German Sinti and Roma (the latter is amongst the founders of the Alliance for ERI);

- In the last decade other institutional projects have emerged, such as the Decade for Roma Inclusion (2005-2015) - a multinational project backed by the World Bank, OSI, UNDP, OSCE, the CoE, the ERTF and national governments aimed at promoting Roma inclusion- and the European Platform for Roma Inclusion (from 2008 onwards) which brings together the EU, IOs and national governments $^{20}$;

- The NRIS (National Roma Integration Strategies, 2011-2020), were developed in almost all EU countries in 2011-2012 following ten basic principles (European Commission, 2012), and revolved mainly around 'bringing up to level' Roma communities with mainstream European societies on the four pillars of health, housing, education and employment. Additionally, the programmes ROMED (Roma mediators) and ROMACT (capacity-building for local administrations to work with vulnerable Roma population) have been implemented, albeit not in all countries and managed by the Council of Europe $^{21}$. The Alliance of Cities and Regions for the Inclusion of Roma is another CoE-sponsored platform that has endorsed the ERI.

Against the background of Roma-targeted European policy developments, of the wider changes in migration and integration politics of the past few years, and of the evolution of the Roma civil society movement(s), ERI has been in need to situate itself among the already existing Roma networks, policies and programmes, and so far has struggled to do so. There are a number or reasons for this, and its supporters might argue that its mandate and mission have been grossly misinterpreted. In the next section I will go over the main criticism that it has received, organized by what I identify as being the three main 'threats' or liabilities of the project. These are, I argue, the dangers of reification (that ERI's recognition struggle might end up simplifying and reifying Roma identity), of displacement (that ERI's recognition struggle risks eclipsing the socioeconomic issues of redistribution) and of misframing (that ERI's recognition struggle is elitist, undemocratic, nontransparent and that it misrepresents the community's boundaries).

These reflections, which attempt to problematize the existing debate rather than resulting in any strong "taking of position" on the desirability or not of ERI, are based on qualitative analysis, and the empirical material they build upon has been gathered according to the principle of triangulation between secondary sources (legal and policy

\footnotetext{
${ }^{20}$ Some see in these recent multinational projects that attempt to bridge the European level and national governments on Roma inclusion the weakening of the ERTF (Jacquot \& Vitale, 2014).

21 For information on the National Roma Integration Strategies, see "EU and Roma" at http://ec.europa.eu/justice/discrimination/roma/index_en.htm. For information on the ROMED and ROMACT programmes, see http://coe-romact.org/.
} 
documents pertaining to the ERI's creation and to Roma targeted policies and legal definitions more in general), participant observation by taking part in a number of events that have been carried out over the past few years by the epistemic community that works on this topic, by following the ongoing email exchanges within the EARNS, as well as through informal conversations with promoters of ERI, EU officers and other stakeholders involved in the process ${ }^{22}$.

This article being part of a larger long-term research, some of the background information was also drawn from interviews with national policy-makers involved with the drafting and/ or implementation of the Roma integration strategies (in Italy and Spain), personal involvement in European Commission and Council of Europe activities, programmes and projects, as well as in a wider ongoing reflection amongst colleagues working in academia, in NGOs and in governmental organizations on how to bridge information and transfer knowledge between (and within) different fields to contribute to evidence-based inclusion policies.

\section{Main Criticisms. The Cultural, the Economic and the Political}

Analyzing the debates, the concept notes, the exchanges between the different actors that have expressed their opinion on the set up of a European Roma Institute so far, taking into account their official and unofficial statements ${ }^{23}$, the main concerns of the critics to ERI seem to be of three fundamental types: cultural (the problem of reification), socioeconomic (the problem of displacement) and political (the problem of misframing).

I here summarize the main concerns of each, in order to make explicit the issues raised and the spheres of concern, to see which have been or can be successfully addressed, and which ones not (or with more difficulties). Also, a close look at each individual aspect can help challenge broad generalizations and distinguish between critiques based on the form the institute is taking, on its competences, and help avoid misinterpretations.

\footnotetext{
${ }^{22}$ In practice, this consisted of closely following the development of the ERI over the past two years, particularly by taking part in the two days closed workshop and one day open conference "Nothing about us without us", where the ERI project was presented and debated (Budapest, October 2014) and which resulted in a Special Issue of the Rights Journal of the ERRC (Ryder et al., 2015); by participating in various EANRS meetings and in its final showcase event, which took place in Strasbourg in April 2015 and included a roundtable reflection with Ulrich Bunjes, CoE's Special Representative of the of the Secretary General for Roma issues at the time, accompanied by formal and informal reflections around the material circulated on this topic, such as Yaron Matras' post-mortem or 'balance sheet' of the network, which was mostly about ERI (Matras, 2015). Other events and conferences attended in which the role and desirability of a Roma Cultural Institute were discussed include "When the Oil Runs Out, People Will Need Horses” (London, June 2015) and “Challenging Romanophobia” (University of Brighton, November 2015), in which members of the Alliance for ERI presented their vision of the institute and made a case for its necessity.

${ }^{23}$ For a not exhaustive, but still relevant and useful chronology of the plans for a European Roma Institute, see A Chronology: Plans for a European Institute (Fosztó, 2015).
} 


\section{V.1 Cultural concerns (or concerns about culture) and counter arguments}

Some of the criticisms raised to the ERI have revolved around the legitimacy of cultural production. Preoccupation on behalf of (mostly non Roma) Romani scholars that the ERI would lay claim to academic authority and turn into some kind of censor or official arbiter for the standardizing of what Romanipé is or should be, have been echoed by the European Roma Travellers Forum's statement on ERI: "Culture is intimately linked to the life and identity of the community. It can be promoted and assisted but it cannot and should not be directed from above by a political organization. A top-down imposition of a standard culture would deny the rich pluralism of genuine Roma traditions” (European Roma and Travellers Forum, 2015, p. 2).

On a similar note, Monica Rossi has noted: "Theoretically, the idea of a 'Roma culture' (ANY culture, really) as a unique block is meta historic as a category [...]. The term 'culture' refers to an anthropological concept ideated in 1871 by E.B. Tyler and is a tool which was born under a scientific paradigm that contemporary anthropologist call 'essentialism'. In the globalized and fundamentally intercultural world we are living in, the use of such concept is unsustainable in scientific terms as it suggests a static vision of human groups that no longer exists, thus making the very name of the Institute obsolete" (Rossi, 2014) ${ }^{24}$.

In response to this critique, ERI promoters have noted that cultural institutes have been set up in history by virtually every national, regional and cultural minority. One member of the Alliance put it this way: "Well, I see ERI as a space for cultural autonomy of Roma, where Roma get together and refine this public space. Not as a national state, but for issues that are important for our identity, for our priorities, for shaping a discourse, reacting to something. I think that was the general hope.”

Reflections upon the role of the institute invariably bring up, as is to be expected, questions about ownership and Roma cultural production. One supporter of the institute reflected upon the role that the ERI could play by calling into cause the issue of Roma participation and having a voice in shaping the ways in which Roma are portrayed:

"In terms of culture I think we need to take the initiative: we know what our culture is, we can share our cultural experience, and it's for us to share it. It's not for other people to define us. This is where I see the role of arts and culture. [...] And I think that if we do a good job artisticallygood quality writing, good character development, just like any good piece of art, that has universal themes and concepts, then that will translate and will be something to be shared with non Roma as well, because we'll be sharing the universality of our human experience. But we can only do that if we are in control, through institutes like ERI,

\footnotetext{
${ }^{24}$ This brings up the open-ended debate on whether the Roma can and should be considered one ethnic minority to begin with, which has been explored in detail elsewhere (Friedman et al., 2015; McGarry, 2014; van Baar, 2011; Vermeersch, 2012).
} 
through artists that have a vision of something creative, original and that can be shared. [...] We need culture, we need stories, we need paintings, we need poetry, we need everything. That is what establishes a relationship.”

There is, of course, always an inherent risk in the institutionalization of any expression of identity and culture, in that such an operation always requires a simplification of sorts, but this is far from being a case unique to the Roma, or about Roma cultural identity. It should suffice to remember France's attempt to organize a forum to debate and define "Frenchness" a few years ago and its failure, despite the body politics behind it being one of the oldest, most centralized and homogenized existing nation-states ${ }^{25}$.

The wider issue with respect to the Roma has to do with the fact that this process is still in the making, and as such there seems not to be (as of yet) shared foundational myths or cultural traits that are already agreed upon and accepted by the whole of the groups included under the cloak of Roma-other than the past and present widespread discrimination, which in turn risks being framed as an identity trait in and of itself. Referring to the European Commission's definition used in the Framework Strategy document of 2012, Matras has rightfully pointed out that "Although an effort can be recognized here to confront stereotypes through emphasizing that the majority of Roma are sedentary, the definition is self-contradictory in referring, on the one hand, to completely separate populations such as Sinti/Kale, the Gens de Voyage and the vague notion of 'Travellers', and on the other hand, to 'similar cultural characteristics'. There are, empirically, no similar cultural characteristics that can help identify the groups named in this definition” (Matras, 2013, pp. 37-38). However, very similar statements could be made with respect to virtually every people now constituting a nation, previously to the processes of nation-building and state-building that took place over the past centuries. The difference and specific difficulty of the Roma in producing and establishing a set of 'similar cultural characteristics' is not so much that Romanés is not spoken by all Roma, but rather that this endeavor involves a minority that does not have a strong territorial concentration and whose members are also, beyond being Roma, nationals of different European countries who have an already strong(er) identity they often subscribe to.

Another criticism raised to ERI that falls in the cultural realm is that it claims to want to educate non Roma about Roma culture, but that by creating a Arts and Culture Institute which is explicitly Romani, it fosters cultural self-segregation. To this, one of the ERI founders has responded:

"The role of ERI is to help Roma artists to give them visibility, to come together and work together. And they are of course free not to do so or to go mainstream, but there are currently 10.000 Roma works rotting in

\footnotetext{
25 In 2009 Nikolas Sarkozy charged Éric Besson, the Minister of Immigration, Integration, National Identity and Mututally-Supportive Development at the time to organize a "[g]reat debate on national identity”(see Jeannot, Tomc, \& Totozani, 2011; Le Monde, 2009a, 2009b).
} 
archives and improper spaces in Central and Eastern Europe, and do you know how many Roma artists were ever exhibited in mainstream cultural spaces? Two of them. So how can we talk about segregating Romani arts and culture, when it doesn't in fact have any visibility at all?”

All these critiques are, in one way or another, rooted in the preoccupation that the identity model of recognition tends also to reify identity. In Nancy Fraser's words, "Stressing the need to elaborate and display an authentic, self-affirming and selfgenerated collective identity, it puts moral pressure on individual members to conform to a given group culture. Cultural dissidence and experimentation are accordingly discouraged, when they are not simply equated with disloyalty. So, too, is cultural criticism" (Fraser, 2000, p. 6). The by-product of recognition can be, in this sense, misrecognition: by reifying group identity it might overshadow the struggles internal to the group for authority and the politics of cultural identification, lending itself to simply reproducing the dynamics it was born to fight against. Whether the ERI is successful in its bid for the promotion of arts and culture as a means to empower Roma artists and intellectuals largely lays in the mechanisms and structures that it will set up to cope with this risk. One of its supporters elaborated on the potential of the content of Roma artistic production with the following:

"When I'm talking about a culture of Roma, by Roma, for Roma, I am talking about creating something new, something avant-garde. I am talking about creating something that is not excluding traditional Roma dance and music, but not exclusive to that. There are new things that we can develop because we are a culture, and we are a people, and just as every other culture and other people we are continuing to evolve. There are new things that are happening: we are not stuck in time, even though often we are studied as if we were stuck in time, in anthropology and sociology. And I think that that is something that art and culture can help bring to light."

\section{V.2 Socioeconomic concerns and counter arguments}

These kind of criticism largely stem from the fact that the meaning of integration, originally used in EU documents as a policy to fight social exclusion (Daly, 2006) has in more recent times come to indicate immigrant minorities' route to becoming part of their host country, and has been further redefined in the case of Roma to (re)include a socioeconomic dimension.

As Monica Rossi wrote in her position piece on the ERI, "Regardless of how you portray the Roma (music, artistic contributions etc. etc.) citizens will continue to have in mind the image of destitute Roma begging with their children and living in shanty towns [...]. It is not clear how the situation of destitute Roma will be improved by the existence of this Institute. [...] If you solve the problems at the ground level, also the perception of Roma citizens by non Roma citizens are going to improve, but it must be based on the creation of real life opportunities for mutual exchange. In a Europe 
dominated by the crisis which is affecting all Member States with severe cuts to social services, money should be invested in initiatives which are sustainable under a costbenefit perspective” (Rossi, 2014, p. 2).

Without entering the debate on the sustainability of culture (Littoz-Monnet, 2007; Psychogiopoulou, 2006; Tretter, 2011), this position makes a claim that cultural productions can neither serve as a substitute to anti-discrimination, nor that it is realistic to expect that cultural performance and the arts can fill a gap in the fight against prejudice and exclusion, or encourage states to enforce equality and human rights legislation.

This is a rebuttal of the claim made in the concept note for ERI: "Sectoral policy achievements have [...] been insufficient to produce a major and deep change, not least because they address primarily socio-economic challenges without tackling the root causes that stand in the way of meaningful progress: ignorance, hatred and mistrust" (The Alliance for the European Roma Institute, 2015, p. 2) and can be articulated in a few different points. On the one hand, Roma cultural performances have been widely appreciated (and at time appropriated) by majoritarian societies over the centuries, yet racism against Roma continued to prevail. On the other hand, the European Roma and Travellers Forum has claimed that "is absurd to decry socio-economic efforts. Ignorance, hatred and mistrust are intimately linked to the living conditions of a majority of the Roma and the first step against anti-Gypsyism and eliminating stereotypes is to provide the Roma with decent housing, education and employment and helping them to enter into roles in which they have hitherto not been accepted." (European Roma and Travellers Forum, 2015, p. 1) ${ }^{26}$.On a similar note, Martin Kovats, ex advisor to the office of Commissioner Spidla on the development of the European Roma Platform and Common Basic Principles for Roma Integration ${ }^{27}$, and more recently special adviser to ex Employment Commissioner László Andor, formulated in clear terms what, borrowing from Fraser, I have called the risk of displacement: “Aren't ignorance, hatred and mistrust more likely to be symptomatic of social and economic relations than their 'root cause'? [...] In making the 'root causes' of poverty, exclusion and discrimination (as well as of multimillion euro policy failure) matters of the mind, no consideration need be given to the structural and systemic factors that many of us believe play an important role in how Roma is understood. The system is fine, just the people that are wrong. They think wrong thoughts about Roma. Furthermore, it is suggested that these wrong thoughts are essentially a legacy of the past (rather than

\footnotetext{
${ }^{26}$ The odd thing in the official statement issued by the ERTF on the non-paper that was leaked about the initial plans to set up ERI was that they reproduced, practically verbatim, the positions expressed by Yaron Matras in EANRS.

${ }^{27}$ The 10 Common Basic Principles for Roma Integration constitute the guiding principles for the Framework on Roma Integration 2020, and are: 1) Constructive, pragmatic and non-discriminatory policies; 2) Explicit but not exclusive targeting; 3) Inter-cultural approach; 4) Aiming for the mainstream; 5) Awareness of the gender dimension; 6) Transfer of evidence-based policies; 7) Use of European Union instruments; 8) Involvement of regional and local authorities; 9) Involvement of civil society; 10) Active participation of the Roma. While point 3 can be interpreted in ways that might lead to cultural recognition policies, the whole approach is clearly geared to achieve equality of opportunities in the socio-economic dimension.
} 
generated within contemporary society). What is required is re-education or at least some good PR and the promotion of a 'positive image'. These neo-liberal ideology may be the answer, but there is no reason to think so" (Kovats 2015, EARNS email exchange).

Nancy Fraser, in her 2000 article on Rethinking Recognition, identified two different possible branches of the issue of displacement: one possibility is to see misrecognition as a problem of cultural depreciation, so that the origins of injustice are seen in discourses, and not as socially grounded, institutionalized norms. The other option is to acknowledge that cultural injustices are linked to economic ones, but to see the problem from a culturalist perspective, thus assuming that maldistribution is simply a secondary effect of misrecognition. The ERI positioning, as presented in its original concept note, could be associated to this second way of seeing things which understands economic inequalities as expressions of cultural hierarchies: "It follows from this view that all maldistribution can be remedied indirectly, by a politics of recognition: to revalue unjustly devalued identities is simultaneously to attack the deep sources of economic inequality; no explicit politics of redistribution is needed" (Fraser, 2000, p. 4).

In short, what comes first, poverty or the stereotypes about the poor? This begs an additional question of whether, and eventually how much, the stereotypes about the Roma have to do with mental associations of the stereotypes of marginalization with an ethnic group, what kind of contact exists between members of majority society and Roma individuals and communities, and what role cultural production and representation (particularly mainstream media) plays in this.

One commentary of an ERI supporter when asked to locate the socio-economic issue within the making of the ERI was: "Because when we start talking about the confusion between class/ socio-economic status and ethnicity, when that becomes a problem, as it is in media and very much in Europe today... If we have people who are Roma and who are middle class but who are passing for white, then maybe at some point they intermarry and maybe they don't share everything with their children, and Roma people are also forgetting that they are Roma, of Romani heritage. That's also a problem."

\section{V.3 Political concerns and counter arguments}

The main criticism related to what I have identified as the problem of misframing has to do with whether ERI is an independent institute or part of an intergovernmental agreement within the Council of Europe (something similar to what the ERTF used to be). According to the Alliance, ERI is to be an independent body, with no ambition of turning into a political representative organization aiming at replacing existing structures or competing with them (Brooks June 2015, EARNS email exchange). 
In response to this claim, concern has been expressed about the difficulty of playing a genuinely independent role when the funders are two big players of Roma identity politics themselves (Matras September and November 2015, Kovats July 2015, EARNS email exchange). The opening statement of the 2015 Alliance for ERI concept note on the creation of the Institute reads “ The 'European Roma Institute' (ERI) is proposed as an independent organization with the mission of increasing the self-esteem of Roma and decreasing negative prejudice of the majority towards the Roma by means of arts, culture, history, media” (The Alliance for the European Roma Institute, 2015, p. 1). The same concept note, however, also identified as one of ERI's core functions that of providing policy advice: "As a policy adviser ERI will provide expert advice in its areas of competence, when required by the Council of Europe, its members and other partners” (The Alliance for the European Roma Institute, 2015, p. 3).

It can of course be argued that "its areas of competence" having been identified as arts and culture, there is no competition between the ERI and organizations such as the ERTF, nor is there necessarily a conflict of interest in being the beneficiary of the Council of Europe's policies, and providing advice to the same body on issues regarding Roma culture. This however becomes less clear cut should ERI start advising the Council of Europe, its members, or other partners on topics that are of political nature, such as inclusion policies and plans for Roma minorities.

This is a different matter from the debate around who holds legitimacy of cultural production on Roma. As mentioned in the section on cultural criticism, some scholars expressed their concern about the potential consequences of appointing an official arbiter (ERI) in matters of (Roma) cultural legitimacy. Regarding power structures and the vision of ERI as a threat that might 'police culture' and oppose scholarly meritocracy, it has been pointed out that there already is, and there has been for quite a long time, a strand of literature and of specialized scholarship on Romani culture that has, for better or for worst, shaped the terms of the debate up until now. The fact that these studies have so far come mostly from non-Roma academics, and not from Roma activists, artists or lobbyists does not make them, per se, more objective, since meritocracy itself is shaped by a cultural understanding of worth and deservingness.

In the words of a member of the Alliance for ERI:

"On the issue of power structures I think we have to go beyond just talking about media: of course it is an important factor in reproducing and strengthening anti-Gyspsysm, but we have to look beyond it. And another important arena where anti-Gypsysm is produced and reproduced is academia. We have to touch on this, because what happened, and what has been an interesting experience to observe about ERI, is that opposition to this initiative has come from two circles, mainly: one were some Roma from the ERTF, because they have a vested interests in securing more resources for themselves; and then it was a bunch of non Roma academics manipulating discourses and ideas about ERI that we chose not to answer to. About meritocracy and the objective, scientific 
approach to social sciences dealing with Roma, this critique really is nonsense: because on the one hand it is assumed that academia is guided by meritocracy, when it is very clear that is not only guided by that. [...]Too often you hear the argument that if you are Roma, you cannot be an academic on Roma studies, just because you would be biased. I don't know how to react to this, and how to overcome these discourses, because I would expect a more friendly environment, I expect that these scholars would understand what Romani culture is. And there are moral and ethical considerations...I simply don't know how to work on that.”

While the issue of knowledge production and Roma-led cultural representations pertain to the field of recognition, it is difficult for it not to 'spill over' into politics. Going back to the 'areas of competence' of the ERI (on which advise might be sought from policy-makers), categories become somewhat blurred. Should ERI be exclusively an artistic endeavor, it would most likely not have been met with the same degree of hostility from certain sectors. Art and culture are however never politically 'neutral', and even less so in contemporary Europe, where culture-due to its flexibility and ambiguity-has become a very apt concept for those wanting to defend the existing political order. The idea that racism and inequality are fundamentally a culturalized problem to be tackled by culturalized measures has been found problematic by many (Mokre, 2013), ever more so when it is met by a "trickle down minority social integration" approach in politics, which translates into the proposition "growth first, social and minority inclusion will follow” (Cianetti, 2016, p. 18).

Additionally, frame-setting has to do not only with how the problem is addressed, but also with the 'scale' at which it is addressed, which is among the most consequential of political decisions. According to Fraser, the problem of misframing concerns the boundary-setting of the political, and can be considered the defining form of injustice in the globalizing age. She identifies the problem of misframing where social movements impose 'a national frame on a global problem' (for example by ignoring the responsibility of the financial markets, global economy and offshore factories on social dumping). In the case of Roma identity politics, the critique seems to go along similar lines, but the directionality is reversed, since the concern is that Roma identity is being framed as a European transnational one while what is being overlooked and overridden are the rights of EU citizens who have not only an ethnicity and minority culture, but also citizenship rights.

The wider preoccupation of many scholars is with the 'Europeanization of Roma’ (Friedman et al., 2015; van Baar, 2015; Vermeersch, 2013). In practice, the main concern is that framing Roma as a transnational European minority might have the unintended consequence of 'absolving' single EU member states from (culturally, among other things) integrating the Roma minorities who live on their territory ${ }^{28}$. The

\footnotetext{
${ }^{28}$ By cultural integration I do not mean assimilation, but rather a comprehensive set of policies that could incorporate Roma culture and history into school textbooks while providing Roma with equal opportunities.
} 
risk, as seen by some, is that of naturalizing the fact that Roma minorities are treated as second-class citizens in their own countries.

\section{ConClusions. ON ELITISM, CULTURE AND 'THE IMPORTANT THINGS IN LifE’}

After providing some background for the emergence of Roma identity politics in contemporary Europe, in the previous section I grouped the critiques moved to the project of a European Roma Institute according to three broad categories: cultural (the problem of reification), economic (the problem of displacement) and political (the problem of misframing). In Elizabeth Andersons' vocabulary, these can be thought of as inequalities of esteem -when some groups stigmatize, demean and monopolize honorable status to themselves-, socio-economic inequalities -when different set of rules apply to different groups depending on their socio-economic status-, and inequalities of standing -or political power, in the sense of a society which weights the interests of members of some groups more heavily than others (Anderson, 2010, 2015).

According to the documents, exchanges and debates held about ERI to date, the declared purpose of its proponents is clearly that of tackling the first set of issues: that of cultural recognition and esteem. Nonetheless, given that there are increasing instances in which economic and social problems are constructed as "cultural issues" (particularly in relation to migrant communities, with marginality seen as a 'cultural' ill of the poor), the ways in which ERI will carry out its activities, and what kind of definition of culture its members will adopt, will determine whether the institute is capable of addressing the identified challenges.

The wider picture in which the ERI debate can be situated is that, in modern times, the concept of 'race' has gradually turned into 'ethnicity', and 'ethnicity' into 'culture', which has come to occupy a more subtle, pervasive and versatile social space -a good example of which is what has been labeled "reasonable anti-Gypsism" (van Baar, 2011). In this sense, while the hybridity of Roma identities makes it difficult for Roma to present a coherent 'Romani voice' in cultural terms, McGarry has suggested that "it is the political identity of Roma which has the capacity to change through formal representation in the public sphere with Roma actively determining how they are understood” (McGarry, 2014, p. 770). However, there is no reason to show that political unity might be more easily achieved than cultural representation.

Cultural identity as an economic, status, or upward mobility opportunity also plays a role: Roma culture has historically been appreciated, but generally as a 'low culture' compared to things such as the opera and academic scholarship. This calls into question what the purpose of culture is to begin with, and what is its function.

In this regard, one of the Alliance members commented:

"The main focus of ERI will be to address Roma in a positive way. Because up until now the dominant discourse is that Roma are an issue, 
they have problems, they are a problem ... and we want to show that you can look at Roma from another perspective. [...] To give you an example, when we talk about Roma events, it is always about music, and dancing. That's a folklorization of what we mean by Romani arts and culture. Nobody talks about the works of Roma artists who deserve recognition and visibility. So when people think of Roma culture it is not 'high culture', we always think of Roma 'low culture'...so at one moment, as a joke, I was thinking that we could give ERI a more controversial name, something like 'Roma Academy for Verifying Arts, High Culture, and Top Sciences’.”

Beyond the irony, this statement raises the important point of conceptualizing culture and cultural systems as extensions of power.

The fact that Berlin was chosen as the city where ERI will be set up holds an important symbolic value, as does the recent appointment of Valeriu Nicolae, a Romanian Roma that comes from grassroots activism, as Special Representative for the Secretary General for Roma issues at the Council of Europe. The decision regarding who is appointed as Executive Director of ERI (an open call was launched by the Alliance in August 2016) will give a better sense of the direction in which the project is moving.

As Bourdieu wrote in his Distinction: A Social Critique of the Judgment of Taste, "For an adequate interpretation of the differences found between the classes or within the same class as regards their relation to the various legitimate arts, painting, music, theatre, literature, etc., one would have to analyze fully the social uses, legitimate or illegitimate, to which each of the arts, genres, works or institutions considered lends itself” (Bourdieu, 1987, p. 18). In order to contribute to a meaningful interpretation of these struggles, the role of academia in general, and Romani studies in particular, could and should be that of adopting a more inter-disciplinary and intersectoral approach to the topics of ethnicity, culture, and knowledge production. 


\section{REFERENCES}

ANDERSON, E. (2010). The Imperative of Integration. Princeton: Princeton University Press.

ANDERSON, E. (2015, April 23). "What's Wrong With Inequality?" New York Times. Retrieved from http://opinionator.blogs.nytimes.com/2015/04/23/inequalities-wecan-live-with/?_r=0

BÍRÓ, A., GHEORGHE, N., \& KOVATS, M. (2013). From victimhood to citizenship. The Path of Roma Integration. (W. Guy, Ed.). Budapest: Pakiv European Roma Fund.

BOURDIEU, P. (1987). Distinction: A Social Critique of the Judgement of Taste. Boston: Harvard University Press.

BUNESCU, I. (2014). Roma in Europe: The Politics of Collective Identity Formation. Burlington, VT: Ashgate Publishing Ltd.

CIANETTI, L. (2016). "Minority Integration between (Mis)Recognition and (Mal)Distribution in Contemporary Europe", In IPSA - Politics in a World of Inequality (p. 26). http://doi.org/10.1017/CBO9781107415324.004

COMMISSION OF THE EUROPEAN COMMUNITIES. (1970). Europeans and European Unification. The results of a survey study conducted in February-March 1970 in the six countries of the European Community.

COUNCIL OF EUROPE. (1993). Gypsies in Europe (Recommendation 1203, Parliamentary Assembly, 1993)

COUNCIL OF EUROPE. (2002). The Legal situation of the Roma in Europe (Recommendation 1557, Parliamentary Assembly, 2002)

COUNCIL OF EUROPE. (2014).Towards the creation of a "European Roma Institute" Consultation document prepared by the Council of Europe Secretariat

COUNCIL OF EUROPE. (2015). ERI will spread understanding of Roma culture and challenge stereotypes. Retrieved January 30, 2016, from http://www.coe.int/en/web/portal/-/secretary-general-jagland-european-romainstitute-will-spread-understanding-of-roma-culture-and-challenge-stereotypes

DALY, M. (2006). Social Exclusion as Concept and Policy Template in the European Union (Working Paper Series No. 135). Belfast.

DOYTCHEVA, M. (2015). "Roms et Tsiganes en Europe méditerranéenne: l'actualité d’une question". Confluences Méditerranée, 93(2), pp. 9-26. 
EUROPEAN COMMISSION. (2000)."Council Directive 2000/43/EC of 29 June 2000 implementing the principle of equal treatment between persons irrespective of racial or ethnic origin". Official Journal of the European Communities, pp. 22-26

EUROPEAN COMMISSION. (2010). Roma in Europe: The Implementation of European Union Instruments and Policies for Roma Inclusion - Progress Report 2008-2010. Brussels.

EUROPEAN COMMISSION. (2011). Communication from the Commission to the European Parliament, the Council, the European Economic and Social Committee of Regions. An EU Framework for National Roma Integration Strategies up to 2020. Retrieved from http://eur-lex.europa.eu/legalcontent/en/ALL/?uri=CELEX:52011DC0173

EUROPEAN COMMISSION. (2012). Communication from the Commission to the European Parliament, the Council, the European Economic and Social Committee of the Regions. National Roma Integration Strategies: a first step in the implementation of the EU Framework. Retrieved from http://eurlex.europa.eu/legal-content/en/ALL/?uri=CELEX:52012DC0226

EUROPEAN COMMISSION DG EMPL. (2004). The situation of Roma in an enlarged European Union.

EUROPEAN COMMISSION DG JUST. (2012). Special Eurobarometer 393: Discrimination in the $E U$ in 2012, (November), p. 238. Retrieved from http://ec.europa.eu/public_opinion/index_en.htm

EUROPEAN COMMISSION DG JUST. (2015). Discrimination in the EU in 2015.

EUROPEAN COMMISSION DG JUST. (2016). Tackling discrimination legislation.

Retrieved January 28, 2016, from

http://ec.europa.eu/justice/discrimination/law/index_en.htm\#h2-9

EUROPEAN ROMA AND TRAVELLERS FORUM. (2015). "The views on the European Roma and Travellers Forum on the "revised concept paper on the creation of a European Roma Institute.” ERTF Statement on ERI. Strasbourg. http://doi.org/10.1017/CBO9781107415324.004

EUROPEAN UNION AGENCY FOR FUNDAMENTAL RIGHTS. (2011). EU-MIDIS Technical Report. Methodology, Sampling and Fieldwork.

EUROPEAN UNION AGENCY FOR FUNDAMENTAL RIGHTS. (2016). Second European Union Minorities and Discrimination Survey Roma - Selected findings.

EUROPEAN UNION AGENCY FOR FUNDAMENTAL RIGHTS - UNDP. (2012). The situation of Roma in 11 EU Member States. 
FOSZTÓ, L. (2015). A Chronology: Plans for a European Roma Institute. Retrieved from http://romanistudies.eu/news/eri-chronology/

FRASER, N. (2000). "Rethinking Recognition". New Left Review, 3(June), 1-8. http://doi.org/Article

FRASER, N. (2005). "Reframing Justice in a Globalizing World". New Left Review, 36(Nov Dec 2005), pp. 69-88.

FRIEDMAN, E., SURDU, MIHAI AND KOVATS, M., MARUSHIAKOVA, ELENA AND POPOV, V., PAP, A., CHRISTIANAKIS, M., RADONIĆ, L., ... HEMELSOET, ELIAS AND VAN PELT, P. (2015). Talking about Roma: Implications for Social Inclusion (Vol. 3). Cogitatio Press.

JACQUOT, S., \& VITALE, T. (2014). "Law as weapon of the weak? A comparative analysis of legal mobilization by Roma and women's groups at the European level". Journal of European Public Policy, 21(4), pp. 587-604. http://doi.org/10.1080/13501763.2014.887138

JAGLAND, T. (2014). State of democracy, human rights and the rule of law in Europe. Report by the Secretary General of the Council of Europe.

JÁROKÁ, L. (2008). European Parliament: Motion for a Resolutin.

JEANNOT, C., TOMC, S., \& TOTOZANI, M. (2011). "Retour sur le débat autour de l'identité nationale en France: quelles places pour quelle(s) langue(s)?". Lidil, 44 (Langues, minor(is)ations et marginalisations), pp. 63-78.

KOVATS, M. (2001). "Problems of Intellectual and Policial Accountability in Respect of Emerging European Roma Policy". Journal on Ethnopolitics and Minority Issues in Europe, 2(1), p. 1. Retrieved from http://www.ecmi.de/fileadmin/downloads/publications/JEMIE/2001/Focus112001KovatsComment.pdf

KOVATS, M. (2012). "The EU's Roma role". OpenDemocracy. Retrieved from https://www.opendemocracy.net/martin-kovats/eus-roma-role

LE MONDE. (2009a, October 25). "Besson relance le débat sur l’identité nationale". Le Monde. Paris.

LE MONDE. (2009b, December 16). "Identité, dégâts". Le Monde. Paris. Retrieved from http://www.lemonde.fr/idees/article/2009/12/16/identitedegats_1281368_3232.html?xtmc=identite_degats\&xtcr=156

LITTOZ-MONNET, A. (2007). The European Union and Culture: between Economic Regulation and Cultural Policy (European P). Manchester: Manchester University Press. 
MATRAS, Y. (2013). "Scholarship and the politics of Romani identity: strategic and conceptual issues". European Yearbook of Minority Issues, 10(1), pp. 211-247.

MATRAS, Y. (2015). "European Academic Network on Romani Studies: A balance sheet". EANRS, (April), pp. 1-10. Retrieved from http://www.coe.int/t/dg4/cultureheritage/culture/romastudies/Default_en.asp

McGARRY, A. (2014). "Roma as a political identity: Exploring representations of Roma in Europe". Ethnicities, 14(6), pp. 756-774. http://doi.org/10.1177/1468796814542182

MOKRE, M. (2013). "On the Culturalization of Inequality in Capitalist Democracies". EIPCP, pp. 2-5.

PSYCHOGIOPOULOU, E. (2006). "The Cultural Mainstreaming Clause of Article 151(4) EC: Protection and Promotion of Cultural Diversity or Hidden Cultural Agenda?". European Law Journal, 12(5), pp. 575-592. http://doi.org/10.1111/j.1468-0386.2006.00335.x

ROSSI, M. (2014). ERI Consultation. Consorzio Nazionale Delle Ricerche (CNR). http://doi.org/10.1017/CBO9781107415324.004

RUIZ VIEYTEZ, E. J. (2014). "Cultural diversities and Human Rights: History, Minorities, Pluralization". The Age of Human Rights Journal, 3(December), pp. 131.

RYDER, A., KOCZE, A., ROSTAS, I., DUNAJEVA, J.-E., BOGDA, M., TABA, M., ... JUNGHAUS, T. (Eds.). (2015). "Nothing About Us Without Us ? Roma participation in policy making and knowledge production". Rights Journal of the European Roma Rights Centre, 2(Special Issue on Roma participation in policy making and knowledge production), p. 106.

SIGONA, N. (2011)."Neoliberalism, anti-Gypsyism and the EU's dream deferred". Lignes, 34, pp. 1-6.

SOLIMENE, M. (2011). "“ These Romanians have ruined Italy ”. Xoraxané Romá , Romanian Roma and Rome". Journal of Modern Italian Studies, 16(5). http://doi.org/10.1080/1354571X.2011.622471

SOROS, G., \& THORBJØRN, J. (2015). Why we are setting up a Roma European Institute. Retrieved from http://www.politico.eu/article/why-we-are-setting-up-aeuropean-roma-institute/

STOKES, B. (2015). Pew Research Center. Global Attitudes \& Trends. Retrieved June 3, 2015, from http://www.pewglobal.org/2015/06/02/chapter-3-anti-minoritysentiment-not-rising/\#roma-generate-greatest-anti-minority-sentiment 
SURDU, M. (2016). Those Who Count: Expert Practices of Roma Classification. Budapest: CEU Press.

SURDU, M., \& KOVATS, M. (2015). "Roma Identity as an Expert-Political" Construction. Social Inclusion, 3(5), pp. 5-18. http://doi.org/10.17645/si.v3i5.245

THE ALLIANCE FOR ERI, OPEN SOCIETY FOUNDATIONS, \& THE COUNCIL OF EUROPE. European Roma Institute (2015). Retrieved from https://www.opensocietyfoundations.org/sites/default/files/european-romainstitute-concept-paper-20150515.pdf

THE GYPSY LORE SOCIETY. (2016). The Gypsy Lore Society. Retrieved February 15, 2016, from http://www.gypsyloresociety.org/home

TREMLETT, A. (2014). "Making a difference without creating a difference: Superdiversity as a new direction for research on Roma minorities". Ethnicities, 14(6), pp. 830-848. http://doi.org/10.1177/1468796814542183

TRETTER, E. (2011). "The "Value" of Europe: The Political Economy of Culture in the European Community". Geopolitics, 16(4), pp. 926-948. http://doi.org/10.1080/14650045.2011.554465

VAN BAAR, H. (2011). "Europe’s Romaphobia: problematization, securitization, nomadization". Environment and Planning D: Society and Space. http://doi.org/10.1068/d2902ed1

VAN BAAR, H. (2015). "The Perpetual Mobile Machine of Forced Mobility: Europe's Roma and the Institutionalization of Rootlessness", In Y. JANSEN, J. de BLOOIS, \& R. CELIKATES (Eds.), The Irregularization of Migration in Contemporary Europe: Deportation, Detention, Drowning, pp. 71-86. London / New York: Rowman \& Littlefield.

VERMEERSCH, P. (2012). "Reframing the Roma: EU Initiatives and the Politics of Reinterpretation". Journal of Ethnic and Migration Studies, 38(8), pp. 1195-1212. http://doi.org/10.1080/1369183X.2012.689175

VERMEERSCH, P. (2013). "The European Union and the Roma: an analysis of recent institutional and policy developments". European Yearbook of Minority Issues, (9), pp. 341-358. 